\title{
ULTRASTRUCTURAL CHANGES IN THE OVARIES OF INFANT MICE DEPRIVED OF ENDOGENOUS GONADOTROPHINS AND AFTER SUBSTITUTION WITH FSH
}

\author{
BRITTA HARDY, D. DANON, A. ESHKOL AND B. LUNENFELD \\ Department of Biological Ultrastructure, Weizmann Institute and \\ Institute of Endocrinology, The Chaim Sheba Medical Centre, Tel Hashomer, Israel
}

(Received 22nd February 1973)

Summary. The ultrastructure of ovaries of infant mice deprived of gonadotrophins was compared to the normal developmental pattern and to that of animals deprived of endogenous gonadotrophins but receiving FSH.

In the absence of circulating gonadotrophins, structural changes were observed; granulosa-cell nuclei were irregularly shaped rather than round, and the spaces between the granulosa cells disappeared as did the spaces between the granulosa cells and the oocyte.

The most striking effect was observed in the zona pellucida, the width of which diminished and became irregular. The number of cell processes within the zona pellucida was markedly reduced.

These changes are tentatively attributed to alteration in the structure of the granulosa cell. Substitution with FSH partly prevented these changes, indicating that FSH has a rôle to play in the preservation of the integrity of the granulosa-cell membrane.

\section{INTRODUCTION}

Gonadotrophins are required for normal ovarian development in mice during the first 2 weeks of life and, in the absence of gonadotrophic hormones, the development of granulosa and theca cells is impaired (Eshkol, Lunenfeld \& Peters, 1970). Neither the effect of deprivation of gonadotrophins on the zona pellucida, however, nor the nature of the interrelationship among the granulosa cells and between granulosa cells and oocytes in animals deprived of gonadotrophins, has been fully clarified. We have carried out ultrastructural analyses in an attempt to determine to what extent substitution with FSH could prevent the developmental changes observed following deprivation of both gonadotrophic hormones (LH plus FSH) in mice. Deprivation was achieved by neutralizing the endogenous gonadotrophins with rabbit anti-rat gonadotrophins (Lunenfeld, Eshkol, Baldratti \& Suchowsky, 1967). 


\section{MATERIALS AND METHODS}

Littermate newborn ICR Swiss-Albino mice were used in all experiments. One group was injected with $0.1 \mathrm{ml}$ antiserum to rat gonadotrophins (aRG) (Lunenfeld, Eshkol, Baldratti \& Suchowsky, 1967) daily up to the age of 10 days. A second group received daily injections of aRG plus biologically pure human FSH devoid of LH activity (Eshkol \& Lunenfeld, 1967), while the control animals were given $0.1 \mathrm{ml}$ normal rabbit serum daily.

At the age of 10 days, the animals were anaesthetized and after the ovaries had been exposed by abdominal incision, they were removed and processed for light and electron microscopy by the methods described by Eshkol et al. (1970) and by Stegner, Lunenfeld \& Eshkol (1970), except for the use of Epon 812 after dehydration in graded ethanol. Specimens were cut, using the Danon-Yeda Ultramicrotome, and preparations were viewed in a JEM-T-7 electron microscope.

\section{Measurements}

After preliminary observation on alterations in the number and degree of penetration of pseudopodia into the zona pellucida, the following quantitative methods were adopted.

All the measurements were performed on electron micrographs at $\times 30,000$ magnification.

The extent of the granulosa-cell indentations was estimated by measuring, with a map curve measurer, the length of the granulosa-cell membrane bordering the zona pellucida, and comparing this with the length of an imaginary border consisting of a line representing the shortest circumferential distance between the end points.

The number of processes penetrating into the zona pellucida from the granulosa cells and from the oocyte were counted.

The zona pellucida was irregular in width. To obtain an overall estimation, including the variations in width, we have traced a line approximately at the mid-point of the breadth of the zona pellucida. This line was marked at $1-\mathrm{cm}$ intervals on the micrographs $(\times 30,000)$, and the width of the zona pellucida was measured at these points. Histograms were then drawn showing the distribution of the widths.

\section{RESULTS}

\section{Mice treated with normal rabbit serum (control)}

In the 10-day-old control animals, the ovary contained follicles with up to 100 granulosa cells, counted on the largest cross-section of the ovary (Table 1). The oocytes in these were enlarged about six-fold compared to those of newborn animals and were surrounded by a zona pellucida.

The granulosa cells were arranged concentrically in one or more layers. The round nuclei were well delineated and located at some distance from the zona pellucida.

Intercellular spaces could be seen among the granulosa cells. The outer 
Table 1. Mean number of follicles in the ovaries of control mice and those deprived of gonadotrophins

\begin{tabular}{l|c|c|c|c|c}
\hline & \multicolumn{5}{|c}{ No. of granulosa cells in LCS } \\
\cline { 2 - 7 } & 10 to 20 & 21 to 20 & 41 to 60 & 61 to 100 & $>100$ \\
\hline NRS & $46 \cdot 4$ & $67 \cdot 8$ & $39 \cdot 3$ & $21 \cdot 4$ & $3 \cdot 6$ \\
aRG & $59 \cdot 0$ & $55 \cdot 3$ & $8 \cdot 9$ & 0 & 0 \\
aRG + FSH & $46 \cdot 4$ & 75 & $14 \cdot 3$ & $7 \cdot 1$ & 0 \\
\hline
\end{tabular}

LCS $=$ largest cross section; $\mathrm{NRS}=$ normal rabbit serum; $\mathbf{a R G}=$ anti-rat gonadotrophin.

granulosa layer was bordered by a basement membrane, surrounded by elongated theca cells, among which capillaries could be observed containing red blood cells (Pl. 1, Fig. 1).

Electron microscopic analysis of the follicles revealed that, between the theca and granulosa layers, a continuous filamentous basement membrane could be clearly observed. Capillaries were present between the theca cells but did not extend bevond the basement membrane. The granulosa cells of the multilayered follicles were polyhedral in shape and had round or oval nuclei. The granulosa cell population was not homogeneous. Cells having a dark-staining cytoplasm and nucleoplasm were seen among the more numerous light-staining cells (Pl. 2, Fig. 2).

The cytoplasm was generally rich in mitochondria, the Golgi apparatus well developed, polyribosomes were abundant, and rough and smooth endoplasmic reticulum could be seen in the cytoplasm. Vacuoles containing sparse granular and fibrillar material could be observed in most of the cells. Some of these vacuoles were clearly delineated by a membrane, while others were not (Pl. 3, Fig. 3).

The spaces between granulosa cells were often filled with sparse granular and fibrillar material, reminiscent of that present in the intracellular vacuoles (Pl. 3, Fig. 3).

Table 2. Comparative analysis of (A) length of granulosa-cell membrane bordering the zona pellucida and (B) the number of cell processes in the zona pellucida in control mice and those deprived of gonadotrophins

\begin{tabular}{|c|c|c|c|}
\hline & aRG-treated & $\begin{array}{l}a R G+ \\
\text { FSH-treated }\end{array}$ & Control \\
\hline (A) Length* of g.c. border including indentations & $20 \cdot 5$ & $22 \cdot 9$ & 24.9 \\
\hline Length* of g.c. straight line $\dagger$ & $20 \cdot 2$ & $20 \cdot 4$ & $20 \cdot 4$ \\
\hline Length difference in $\% \dagger$ & $1 \cdot 48$ & $12 \cdot 25$ & $22 \cdot 0$ \\
\hline $\begin{array}{l}\text { (B) No. of processes in half of the z.p. adjacent to the } \\
\text { oocyte }\end{array}$ & $\begin{array}{c}9 \cdot 2 \\
(46 \cdot 5 \%)\end{array}$ & $\begin{array}{c}14 \cdot 6 \\
(74 \cdot 1 \%)\end{array}$ & $\begin{array}{c}19 \cdot 7 \\
(100 \%)\end{array}$ \\
\hline $\begin{array}{l}\text { No. of processes in half of the z.p. adjacent to the g.c. } \\
\text { border }\end{array}$ & $\begin{array}{c}1.2 \\
(15 \cdot 7 \%)\end{array}$ & $\begin{array}{c}3 \cdot 3 \\
(41 \cdot 9 \%)\end{array}$ & $\begin{array}{c}7.9 \\
(100 \%)\end{array}$ \\
\hline
\end{tabular}

g.c. = granulosa cell; z.p. $=$ zona pellucida.

* Measured in $\mathrm{cm}$ on prints of magnification $\times 30,000$.

$\dagger$ The imaginary straight line parallel to the oocyte membrane is considered as $100 \%$. 
The granulosa cells bordering the zona pellucida were not in continuous contact with it. In some areas, there were spaces filled with granular and fibrillar material similar to that found in the intercellular spaces while in others elongated processes of the granulosa cells penetrated the zona pellucida (Pl. 3, Fig. 4).

When the length of the membrane of the granulosa cell identations was evaluated in the control ovaries, it was found to be $22 \%$ longer than the straight line measuring that part of the zona pellucida (Table 2). Processes of the granulosa cells could be seen within the zona pellucida in contact with the oocyte membrane and sometimes portions were observed inside the oocyte.

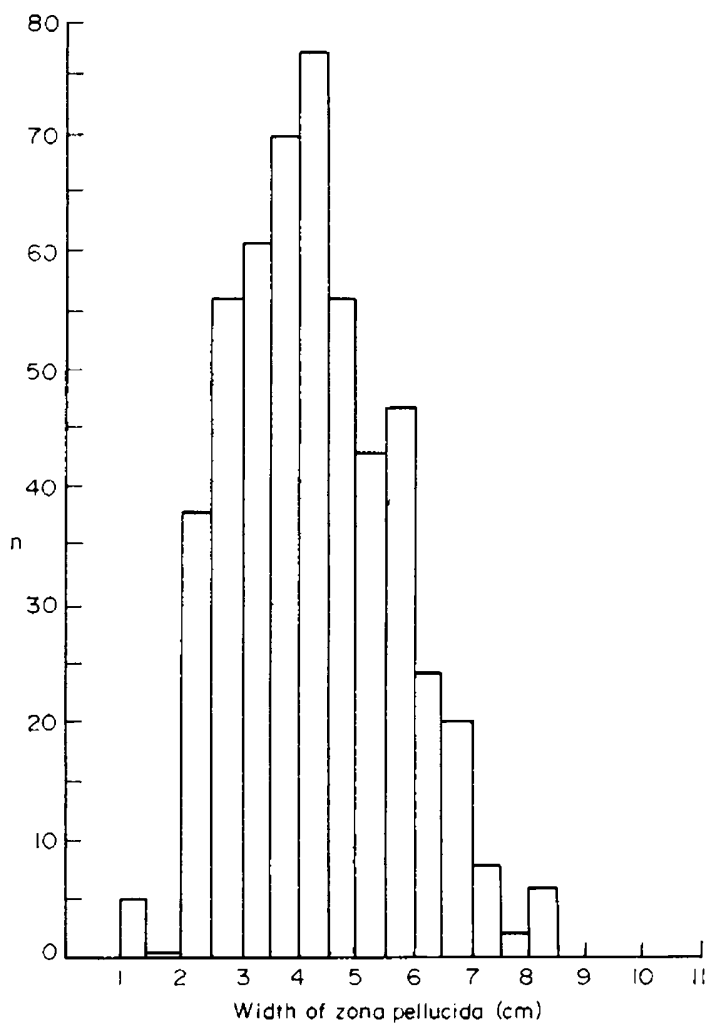

Text-Fig. 1. The frequency of the width of the zona pellucida in control mice.

Processes also projected from the oocyte into the zona pellucida, usually reaching to half its thickness (P1. 3, Fig. 4). There were approximately eight processes in proximity to the granulosa cell membrane per 10-cm length of the zona pellucida (Table 2) and twenty processes in proximity to the oocyte membrane (Table 2).

The width of the zona pellucida was not uniform. It ranged between 2 and $8.5 \mathrm{~cm}$ at $\times 30,000$ magnification, with highest frequencies at 4 to $4.5 \mathrm{~cm}$ (Text-fig. 1).

Contrary to the belief of Hadek (1963), Adams \& Hertig (1964), Hope 


\section{PLATE}

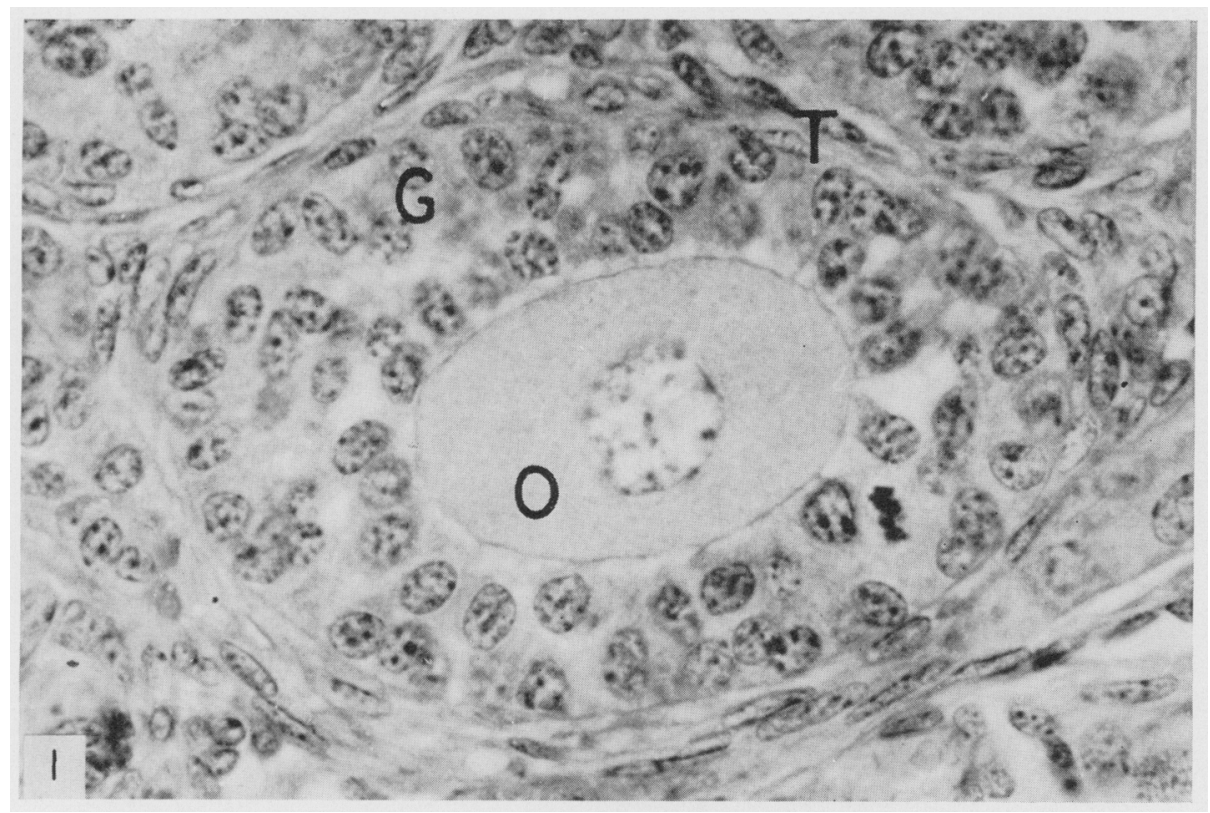

FIG. 1. Light microscopy. Ovary of 10-day-old control mouse stained with haematoxylineosin. Note developed granulosa-cell layer $(G)$ and ample space between the cells. The granulosa-cell layer is surrounded by elongated theca cells $(T)$. O: oocyte. $\times 60$. 
PLATE 2

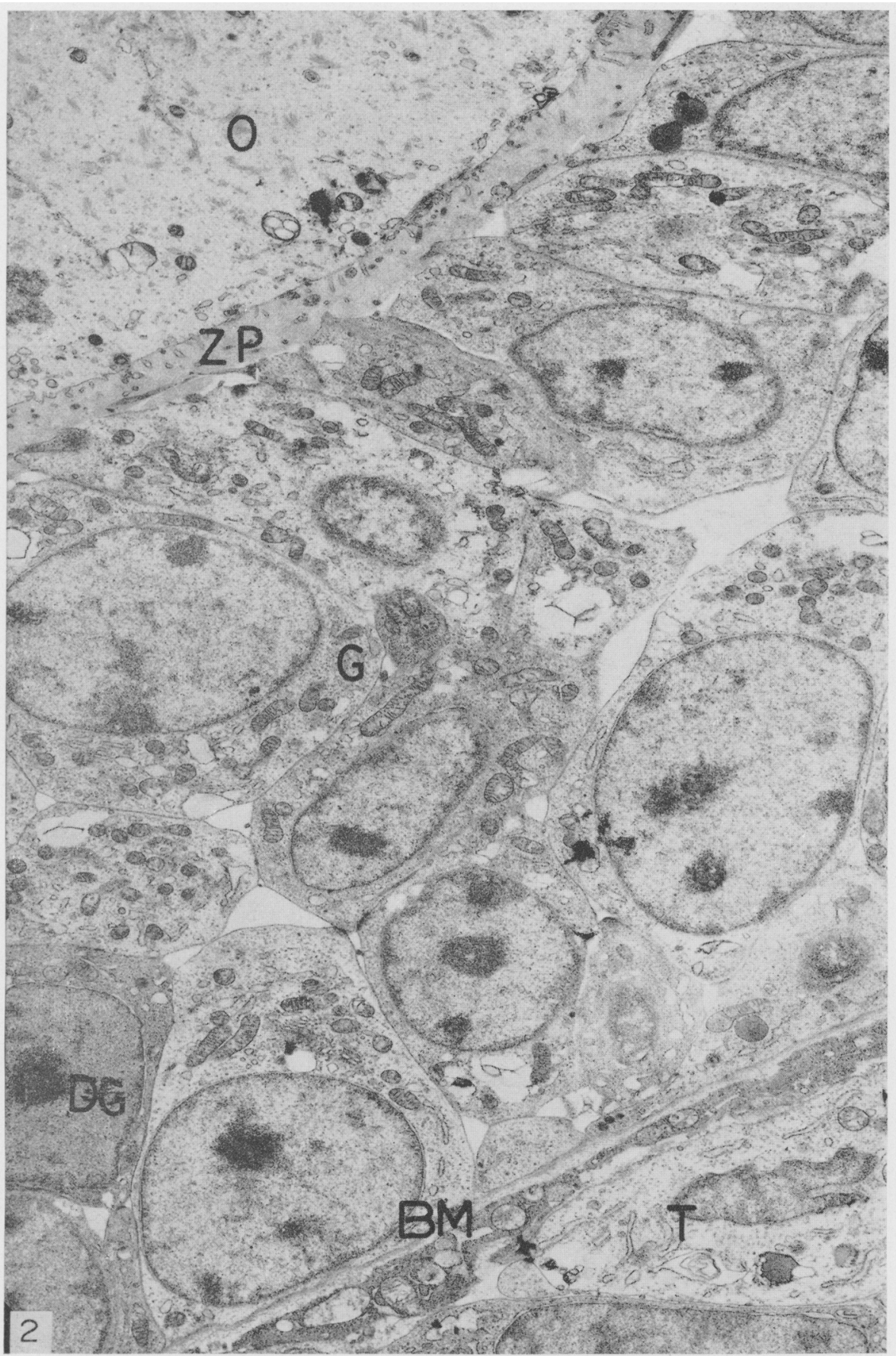

Fig. 2. Electron micrograph of an ovary of 10 -day-old control mouse. Round and oval nuclei of granulosa cells ( $(x)$ can be distinguished. A granulosa cell with dark cytoplasm (DC) is also visible. O : oocyte; BM1: basement membrane; $\Gamma$ : theca colls. $\times 5940$. 


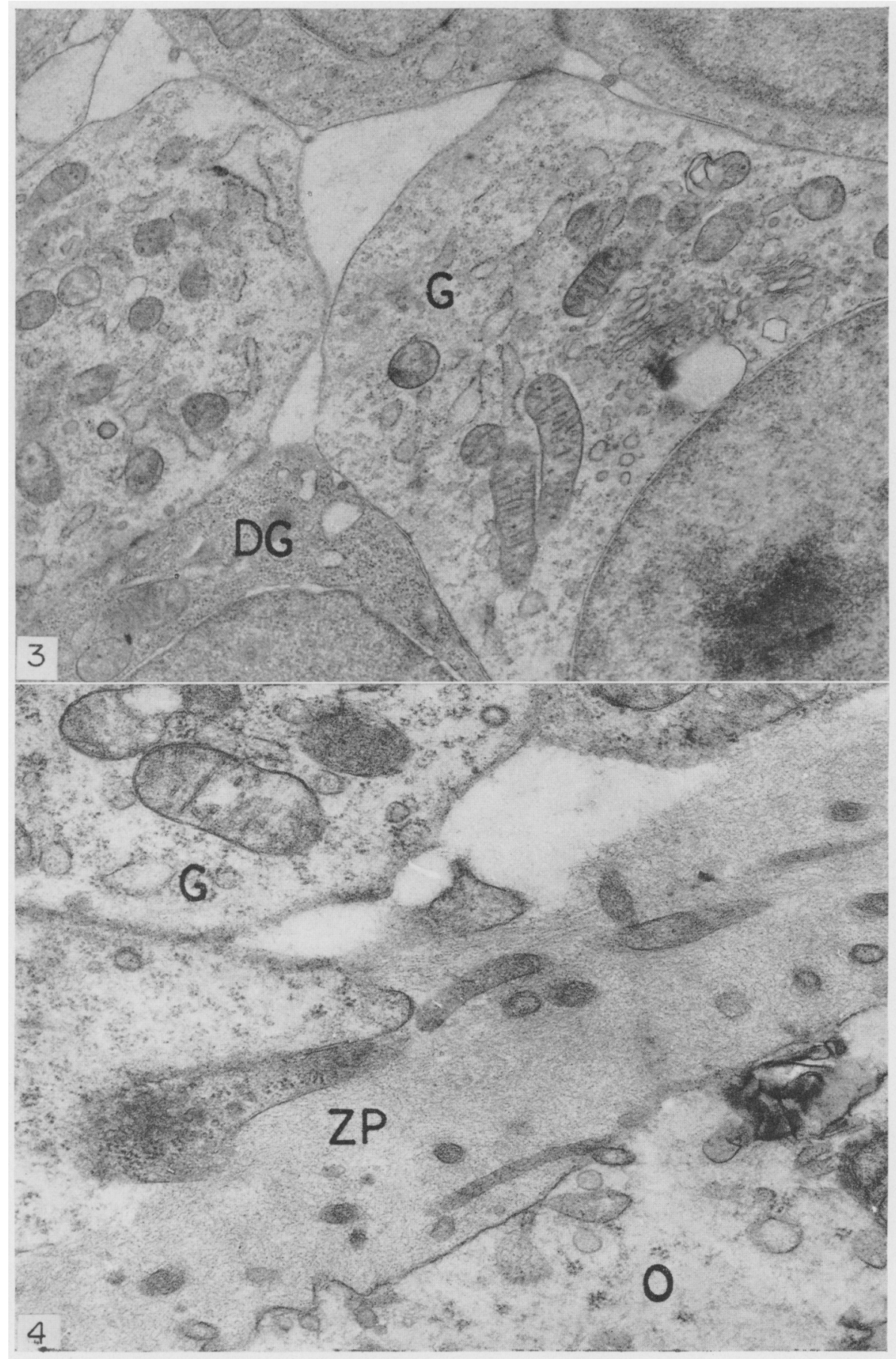

Fig. 3. Ovary of 10-day-old control mouse. Granulosa cells (C) are rich in intracellular organelles, mitochondria. Golgi complexes and endoplasmic reticulum. Intercellular spaces are filled with sparse granular fibrillar material. I dark cell (1)(i) adjacent to a clear cell can be observed. $\times 16.200$.

Fig. 4. Ovary of 10-day-old control mouse The granulosa cells (Cijbordering the zoma bo23 05:16:35AM pellucida (CP) are not in continuous contact with it; between them are spaces filled free access with granular and fibrillar material. Elongated processe's of the granulosa cells are seen within the zona pellucida. (): oocyte. $\times 27,000$. 
PI. ITE 4

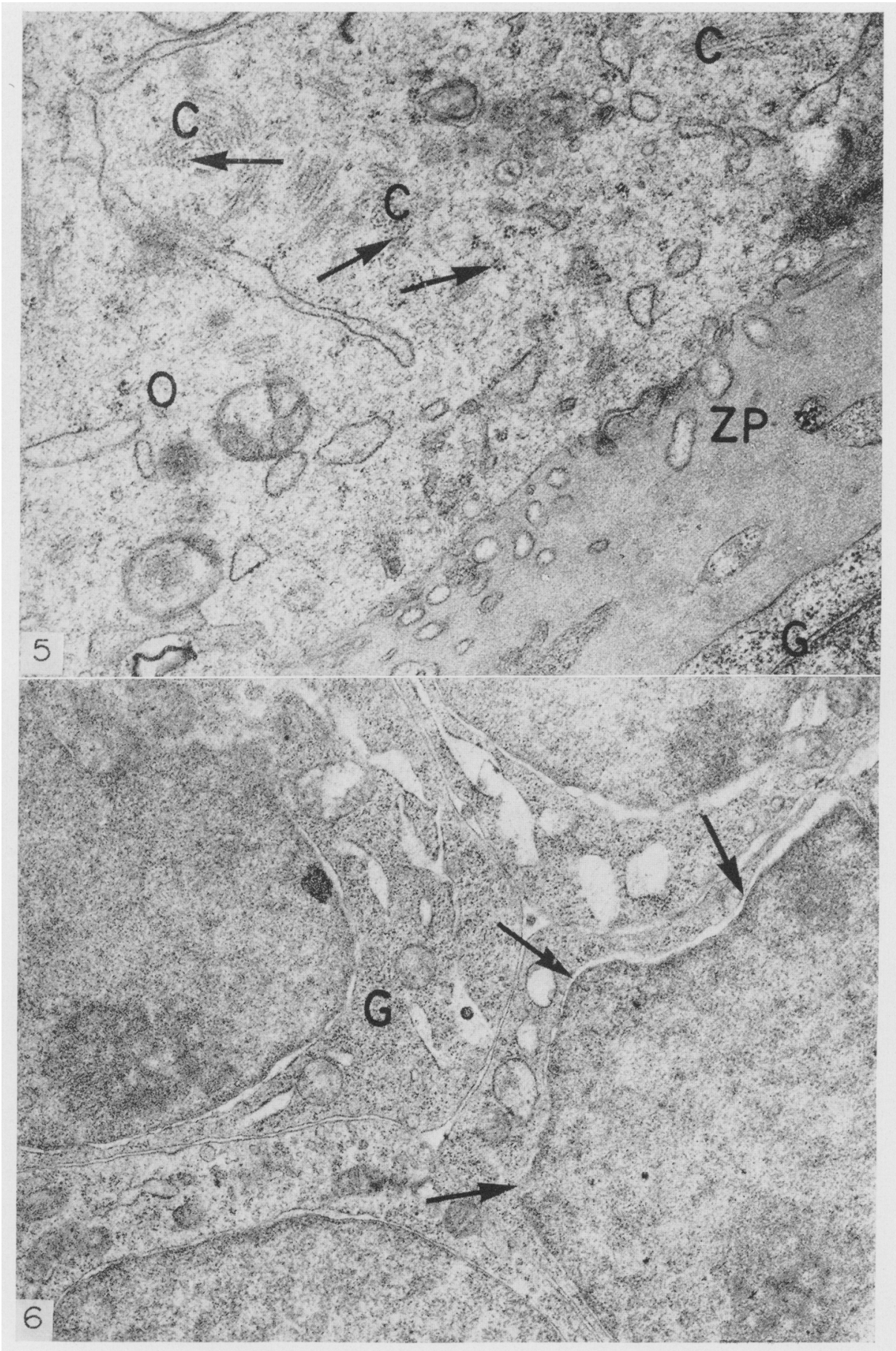

FIG. 5. Qvary of 10-day-old control mouse. Inside the ooryte (O), clusters of filaments (C) are visible. In tranverse section, they appear as dark dots. ZP: zona pellucida, G: granulosa (ell. $\times 25,200$.

FiG. 6. Ovary of 10-day-old aRG-treated mouse. Intercellular spaces between granulosa

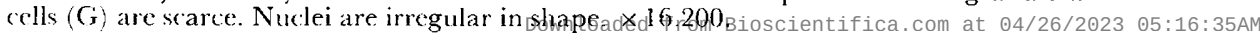




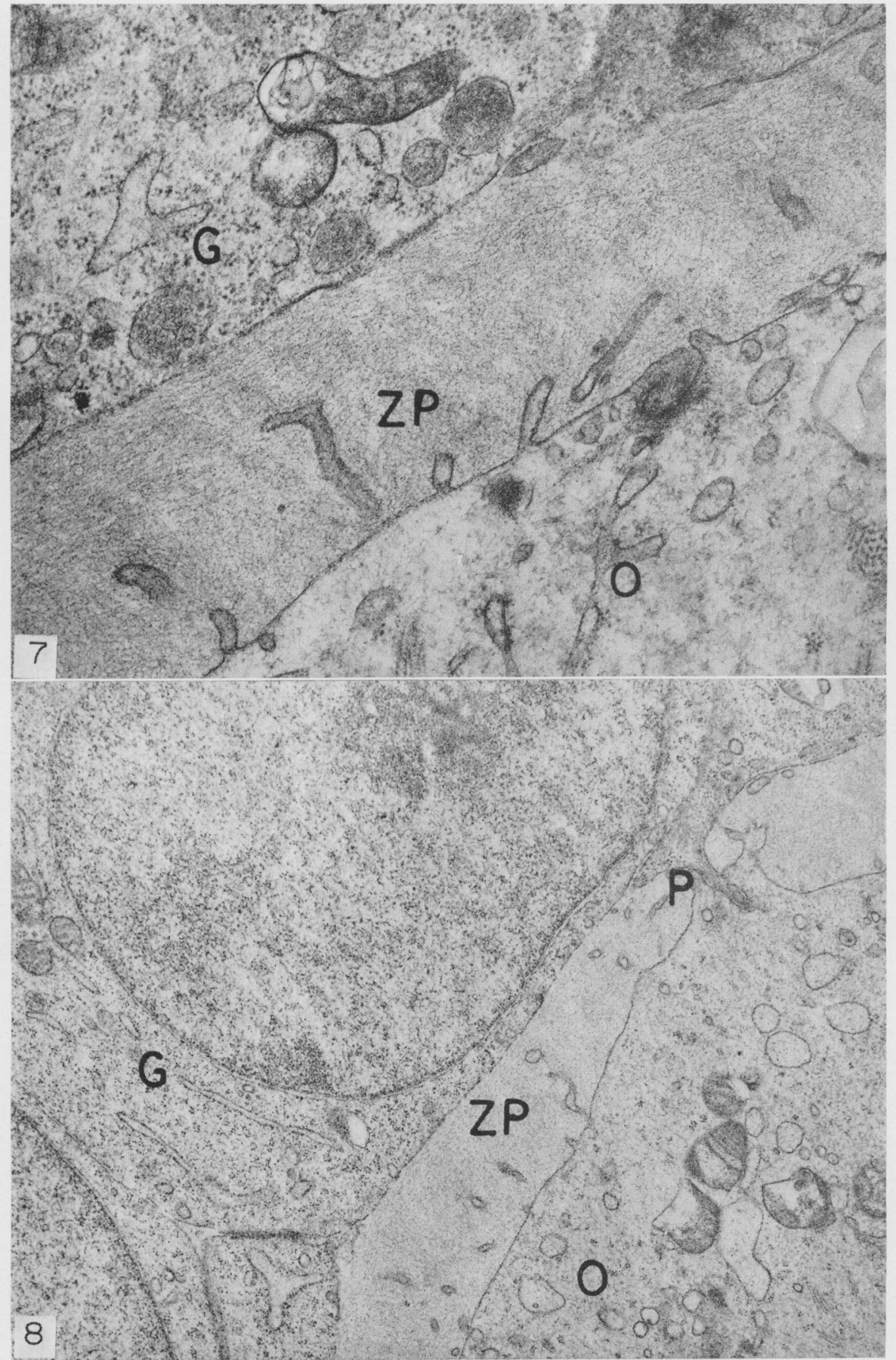

FIG. 7. Ovary of 10-day-old aRG-treated mouse. Granulosa cell $(G)$ processes are only rarely seen within the zona pelludica $(Z P)$; when present, they are less tortuous. The filamentous structure of the zona pellucida is preserved. $\mathrm{O}$ : oocyte. $\times 27,000$.

FIG. 8. Ovary of 10-day-old aRG-treated mouse. Direct contact between the granulosa cell membrane and the oocyte can be seen. Pseudopod-like processes (P) of granulosa cells $(\mathrm{G})$ are visible within the oocyte $(\mathrm{O}) . \mathrm{ZP}$ : zona pellucida. $\times 17.325$. 


\section{PI.ATE 6}

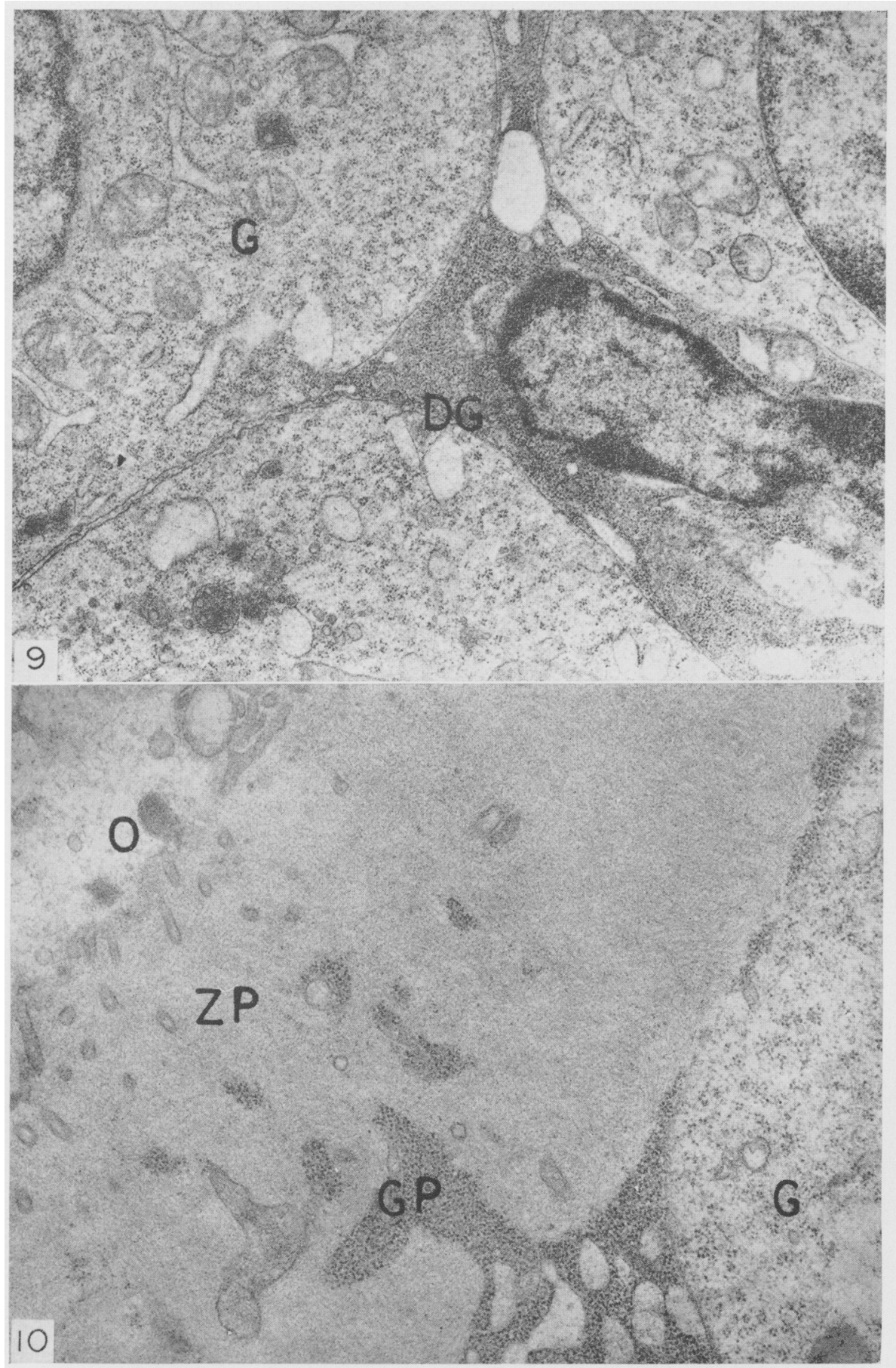

Fic; 9. Ovary of 10-day-old aRG-and FSH-treated mouse. Intercellular space is scarce. A dark cell (DG) among light cells is visible. $\mathrm{G}$ : granulosa cell. $\times 27,000$.

Fig. 10. Ovary of 10-day-old aRG-and FSH-treated mouse. Islets and invaginations of granulosa cell ( $\mathrm{C}$ ) processes ( $\mathbf{G}$ P) packed with ribosomes not surrounded by a membrane are secn within the zona pellucida $(Z, P)$. O: oocyte $\times 17,325$. 
(1965) and Pedersen \& Seidel (1972), the zona pellucida was neither amorphous nor granular but had a filamentous structure (Pl. 3, Fig. 4).

Inside the oocyte, clusters of filaments were seen, which in transverse section resembled clusters of dark dots (Pl. 4, Fig. 5).

\section{Mice deprived of endogenous gonadotrophins}

The follicles in the ovaries of animals deprived of endogenous gonadotrophins contained up to forty cells in the largest follicular cross-section with an occasional follicle containing up to sixty cells (Table 1 ). The theca layer was

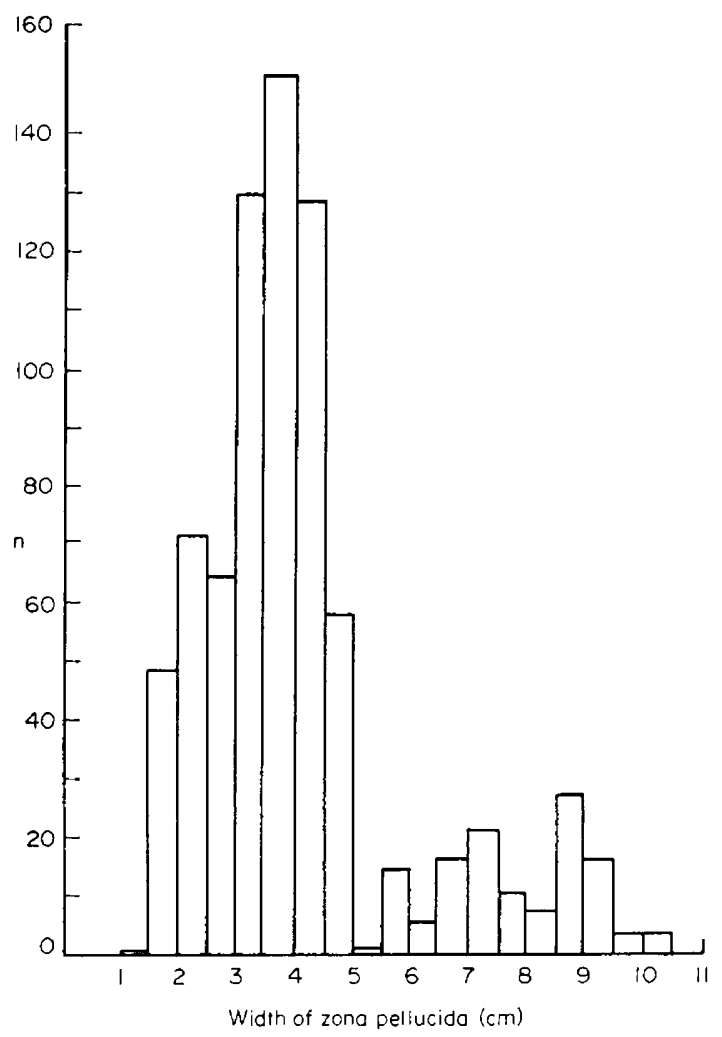

TEXT-FIG. 2. The frequency of the width of the zona pellucida in aRG-treated mice.

sparsely populated by cells and seemed to be narrower than in the control specimens. The vascular system in the ovaries of the antiserum-treated animals appeared less developed when examined by light microscopy.

Electron microscopy revealed that intercellular spaces between the granulosa cells in the follicles were narrow and more infrequent than in the control animals (Pl. 4, Fig. 6). The cell nuclei were irregular in shape (Pl. 4, Fig. 6) and the cytoplasm of the various granulosa cells was more homogeneous than in the controls.

The granulosa cells were in direct, practically continuous, contact with the zona pellucida. This was reflected by a negligible difference between the total 
real length of the sectioned cell membrane and that of the corresponding zona pellucida (Table 2).

Granulosa cell processes were only rarely seen within the zona pellucida (Pl. 5, Fig. 7). When present, they were less tortuous than in the control specimens. The zona pellucida was narrower than that which surrounded similarly sized oocytes in control animals, generally 1.5 to $5 \mathrm{~cm}$ in width, but occasionally up to $10.5 \mathrm{~cm}$ (Text-fig. 2). In some micrographs, direct contact between the granulosa cell membrane and the oocyte was revealed (Pl. 5, Fig. 8).

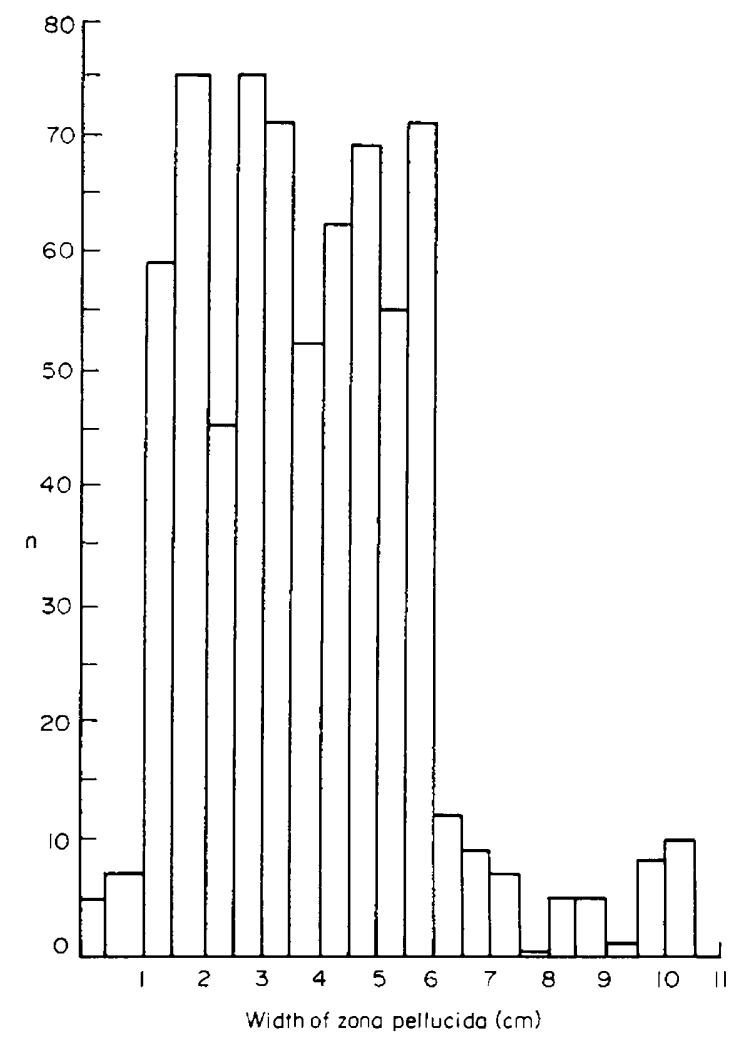

TExT-FIG. 3. The frequency of the width of the zona pellucida in mice receiving FSH substitution.

The filamentous structure did not differ from that in the control animals (Pl. 5, Fig. 7). Pseudopod-like processes were visible within the oocyte membrane (Pl. 5, Fig. 8).

Mice deprived of endogenous gonadotrophins and receiving substitution with folliclestimulating hormone

In ovaries of animals treated with FSH, small blood vessels were seen more often in the theca layer than in animals deprived of gonadotrophin. Granulosa cells with round nuclei were more numerous, but not as many as in the controls and there were still fewer intercellular spaces between the granulosa cells 
compared with the controls. Dark- and light-staining granulosa cells were seen as in the untreated animals (Pl. 6, Fig. 9). The granulosa cell border bore more resemblance to that of the controls (Table 2). Few of the granulosa cell processes in the zona pellucida contained ribosomes. The occurrence of granulosa cell processes in the zona pellucida was more frequent than in the aRGtreated animals, but occurred to a lesser extent than in the controls (Table 2). In a few instances, islets and invaginations packed with ribosomes were seen within the zona pellucida, but without any distinct surrounding membrane (P1.6, Fig. 10). The zona pellucida had a filamentous structure. The processes of the oocyte in the zona pellucida were also more numerous than those observed in the aRG-treated animals (Table 2 and Pl. 6, Fig. 10).

The width of the zona pellucida varied between 1 and $10.5 \mathrm{~cm}$ at $\times 30,000$ (Text-fig. 3). There was no distinct peak-width frequency. Filaments similar to those described within the oocyte in the previous two groups were also seen.

\section{DISCUSSION}

The present observations confirm the results of previous studies by Eshkol et al. (1970) and Stegner et al. (1970) on the dependency of ovarian development, at an early age, on gonadotrophins. This was evident from the reduction in the number of growing follicles in aRG-treated animals as well as from the cell morphology.

The sparsity of blood vessels in the ovaries of animals deprived of gonadotrophin may be considered indicative of the hormonal requirement for appropriate blood supply in the theca layer, but may also be associated with poor development of the follicle.

The granulosa cells are usually arranged in layers with intercellular spaces between them. Deprivation of hormone seems to have increased the intracellular pressure so that the granulosa-cell membranes are under tension and the membranes of neighbouring cells are virtually in continuous contact. Gonadotrophin deficiency is probably responsible for these structural changes. The finding that substitution with FSH did not prevent the disappearance of intercellular spaces indicates that the aRG had additional effects, and is in agreement with the finding of Stegner et al. (1970).

Filamentous and granular material was seen in the enlarged spaces of the rough endoplasmic reticulum and cytoplasmic vacuoles of the granulosa cell. This material appeared similar to that seen in the intercellular spaces (Pl. 3, Fig. 3). It might, therefore, be postulated that the granulosa cells secrete this material as was suggested by Merker (1961) and Wartenberg \& Stegner (1960). The material is also remarkably similar to the denser filamentous structure of the zona pellucida.

The dark-staining and electron dense granulosa cells are infrequent in normal ovaries and very rare in animals deprived of hormone. The fact that they reappear in animals treated with FSH indicates that whatever their function they are probably dependent on FSH.

The number of indentations of the granulosa cell on the border of the zona pellucida is significantly reduced in ovaries of aRG-treated mice. This might 
also be a result of the membrane changes observed in granulosa cells. In FSHtreated animals, the membrane changes induced by $\mathrm{aRG}$ were partly prevented. The fact that the prevention was not complete may be due to inadequate dosage of FSH, or to a requirement for additional hormones. The most striking effect of gonadotrophin deprivation was observed in the zona pellucida and its borders. The number of processes from the oocyte into the zona pellucida was significantly reduced in the animals deprived of hormone. This effect was most evident in that part of the zona pellucida adjacent to the granulosa layer. Treatment with FSH partly prevented this reduction.

From the above observations, it can be tentatively concluded that most, if not all, hormone effects observed in the ovaries of animals deprived of gonadotrophins are due to changes in the structure or permeability of the granulosa cell membranes. These effects are partly prevented by FSH substitution. This indicates that FSH has a rôle to play in preservation of the integrity of the granulosa cell membrane.

\section{ACKNOWLEDGMENTS}

The authors wish to express their gratitude for highly skilled assistance of Mr Stanley Himmelhoch. Part of this study was supported by Ford Foundation Grant No. 670-0470.

\section{REFERENCES}

Adams, E. C. \& Hertig, A. T. (1964) Studies on guinea pig oocytes. F. Cell Biol. 21, 397.

EshKol, A. \& LunENFELD, B. (1967) Purification and separation of follicle stimulating hormone (FSH) and luteinizing hormone (LH) from human menopausal gonadotrophin (HMG). Acta endocr., Copenh. 54, 91 .

Eshrol, A., Lunenfeld, B. \& Peters, H. (1970) Ovarian development in infant mice. Dependence on gonadotrophic hormones. In: Gonadotrophins and Ovarian Development, p. 249. Eds. W. R. Butt, A. C. Crooke and M. Ryle. Livingstone, Edinburgh and London.

HADEK, R. (1963) Electron microscope study on primary liquor folliculi secretion in the mouse ovary. 7. Ultrastruct. Res. 9, 445.

Hope, J. (1965) The fine structure of the developing follicle of the Rhesus ovary. F. Ultrastruct. Res. 12,592 .

Lunenfeld, B., Eshrol, A., Baldratti, G. \& Suchowsky, G. K. (1967) Preparation and characterization of antiserum to purified gonadotrophins from rat pituitary glands. Acta endocr., Copenh. 54, 311.

Merker, H. J. (1961) Elektronenmikroskopische Untersuchungen über die Bildung der Zona Pellucida in den Follikeln des Kaninchenovars. Z. Zellforsch. mikrosk. Anat. 54,677.

Pedersen, H. \& Seidel, G. J. (1972) Micropapillae; a local modification of the cell surface observed in rabbit oocytes and adjacent follicular cells. $\mathcal{7}$. Ultrastruct. Res. 39, 540.

Stegner, H. E., Lunenfeld, B. \& Eshxol, A. (1970) Ultrastructural ovarian changes after deprivation of endogenous gonadotrophins and the effect of FSH and HMG in the deprived immature animals. In: Gonadotrophins and Ovarian Development, p.259. Eds. W. R. Butt, A. C. Crooke and M. Ryle. Livingstone, Edinburgh and London.

Wartenberg, H. \& Stegner, H. E. (1960) Uber die elektronenmikroskopische feinstruktur des menschlichen ovarialeies. Z. Zellforsch. microsk. Anat. 52, 450. 